\title{
Half a Century with the Space Structures Research Centre of the University of Surrey
}

\author{
$\underline{\text { S. Alireza BEHNEJAD }} *$, Gerard A. R. PARKE \\ *PhD Research Student \\ Space Structures Research Centre, University of Surrey, Guildford, UK \\ a.behnejad@surrey.ac.uk \\ ${ }^{\text {a }}$ Professor, Head of the Department of Civil and Environmental Engineering and Director of the Space \\ Structures Research Centre, University of Surrey
}

\begin{abstract}
The Space Structures Research Centre was founded by Professor Zygmunt Stanislaw Makowski in 1963. The Centre is a part of the Department of Civil and Environmental Engineering of the University of Surrey, Guildford, UK. Many different activities have been organised by the Centre since its establishment in areas such as research, publication, teaching, organisation of conferences, as well as, consulting work. This paper outlines the activities of the Centre in the past 50 years and gives an overview of the role of the Centre in the development of spatial structures in the world.
\end{abstract}

Keywords: Space Structures Research Centre, University of Surrey, Professor Z S Makowski, Professor H Nooshin, International Journal of Space Structures, International Conference on Space Structures, Pioneers' Award in Space Structures.

\section{Introduction}

The Space Structures Research Centre was founded in May 1963 by Professor Z S Makowski and has been highly active ever since in helping to further the ideas and promote the utilisation of spatial structures. The main areas of activity encompass research to enhance the methods of analysis, design and the understanding of the behaviour of different forms of spatial structures such as domes, barrel vaults and grids, as well as structural systems such as foldable systems, towers and tension structures. Publication, teaching, organisation of conferences, besides consulting work are example of activities which the Centre has been organising. In 1971, Professor Hoshyar Nooshin was appointed as the Director of the Centre and remained in this position for 28 years. The current Director of the Centre, Professor Gerard Andrew Roger Parke, has taken the responsibility since 1998.
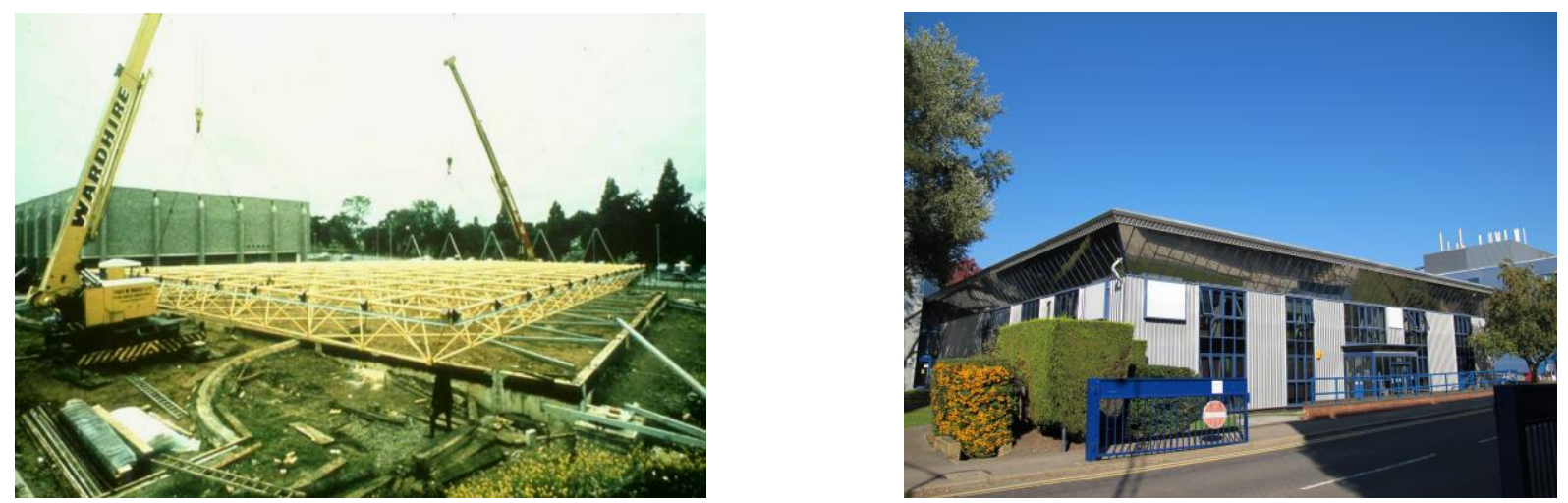

Figure 1: Nodus building which was donated to the Space Structures Research Centre in early 1970s, Guildford,

UK. The left pictures shows the construction phase of the building [5]. 
In early 1970s, a building was donated to the Centre by the British Steel Corporation to use for laboratory experiments on Spatial Structures [1], Figure 1.

\section{Research}

The core aim for founding the Centre was conducting research in the design and analysis of spatial structures. A number of research students have been working on different subjects related to spatial structures in the Centre. The subjects may be categorized into Structural Morphology, Structural Analysis and Construction of different types of spatial structures including shell structures, lattice structures and foldable structures. Figure 2 gives the list of completed dissertations in the Centre since 1967. An electronic copy of some of the dissertations are available via the Surrey Research Insight Open Access [6].

\begin{tabular}{|c|c|c|c|c|c|}
\hline & Degree & Year & First Name & Family Name & Title of Desertation \\
\hline 1 & M Phil & 1967 & $\mathrm{H}$ & Hosseinzadeh & $\begin{array}{l}\text { Analysis of Lamella Structural Systems with Particular } \\
\text { Reference to Lamella Barrel Vaults }\end{array}$ \\
\hline 2 & M Phil & 1967 & Frank E S & West & A Study of the Efficiency of Double Layer Grid Structures \\
\hline 3 & M Phil & 1970 & John & Zerning & $\begin{array}{l}\text { Form and Construction with Hyperbolic Paraboloidal } \\
\text { Shells in Plastics }\end{array}$ \\
\hline 4 & $\mathrm{PhD}$ & 1971 & Nicolas G & Kazma & $\begin{array}{l}\text { Structural Behaviour and Approximate Analysis of a } \\
\text { Double Layer Grid }\end{array}$ \\
\hline 5 & $\mathrm{PhD}$ & 1972 & B C & Neogi & $\begin{array}{l}\text { The Distribution of Bending Moments in a Flat Slab with } \\
\text { Openings }\end{array}$ \\
\hline 6 & $\mathrm{PhD}$ & 1973 & Usam Khairi & Bunni & Instability of Thin-walled Sections \\
\hline 7 & M Phil & 1974 & A G & Collings & $\begin{array}{l}\text { An Approximate Analysis of a Family of Double Layer } \\
\text { Grids }\end{array}$ \\
\hline 8 & $\mathrm{PhD}$ & 1975 & John Warwick & Butterworth & $\begin{array}{l}\text { Nonlinear Analysis and Stability of Elastic Skeletal } \\
\text { Systems }\end{array}$ \\
\hline 9 & $\mathrm{PhD}$ & 1977 & M A E & Bakry & Optimal Design of Transmission Line Towrs \\
\hline 10 & $\mathrm{PhD}$ & 1978 & Alaeddin & Behravesh & A Technique for Structural Optimization \\
\hline 11 & $\mathrm{PhD}$ & 1979 & Nasrollah & Dianat & Elastoplastic Behaviour of Flat Grids \\
\hline 12 & $\mathrm{PhD}$ & 1980 & Mahmood & Haristchian & Formex and Plenix Structural Analysis \\
\hline 13 & $\mathrm{PhD}$ & 1980 & Jaime $\mathrm{S}$ & Sanchez Alvarez & Formex Formulation of Structural Configuration \\
\hline 14 & $\mathrm{PhD}$ & 1981 & Eysa & Salajegheh & Optimum Design of Double-layer Grids \\
\hline 15 & $\mathrm{PhD}$ & 1981 & Chi-Wai & Wong & $\begin{array}{l}\text { The Structural Behaviour of Braced Barrel Vaults with } \\
\text { Particular Reference to Wind Effects }\end{array}$ \\
\hline 16 & $\mathrm{PhD}$ & 1981 & Ian Martin & Collins & Collapse Analysis of Double-layer Grids \\
\hline 17 & $\mathrm{PhD}$ & 1982 & Jan & Bobrowski & Origins of Safety in Concrete Structures \\
\hline 18 & $\mathrm{PhD}$ & 1984 & $\begin{array}{l}\text { Chukwuaka } \\
\text { Michael }\end{array}$ & Anekwe & Reduction Method of Analysis for Dense Space Structures \\
\hline 19 & $\mathrm{PhD}$ & 1985 & Ik Nang Anna & Hee & Plenix Structural Analysis \\
\hline 20 & $\mathrm{PhD}$ & 1985 & Hugh Alan & Howells & $\begin{array}{l}\text { Collapse Behaviour of Space Trusses with Thin-walled } \\
\text { Members }\end{array}$ \\
\hline 21 & $\mathrm{PhD}$ & 1986 & Philip John & Wicks & $\begin{array}{l}\text { Elastic Post-buckling and Imperfection Sensitivity of } \\
\text { Symmetric Structural Systems }\end{array}$ \\
\hline 22 & $\mathrm{PhD}$ & 1986 & OF A & El-Labbar & Formex Graphics in Structural Analysis \\
\hline 23 & $\mathrm{PhD}$ & 1986 & M H & Yassaee & A Formex Approach to Finite Element Mesh Generation \\
\hline 24 & M Phil & 1988 & Parvin D & Pakandam & $\begin{array}{l}\text { Comparison of Behaviour of Three Types of Braced } \\
\text { Domes }\end{array}$ \\
\hline 25 & $\mathrm{PhD}$ & 1988 & Lambros & Babilis & $\begin{array}{l}\text { Micro-Formian for the Analysis and Design of Space } \\
\text { Frames }\end{array}$ \\
\hline 26 & $\mathrm{PhD}$ & 1988 & Mohammad & Ashraf & $\begin{array}{l}\text { Structural Behaviour of Composite Triple Layer Bridge } \\
\text { Grids }\end{array}$ \\
\hline
\end{tabular}




\begin{tabular}{|c|c|c|c|c|c|}
\hline 27 & $\mathrm{PhD}$ & 1988 & $\begin{array}{l}\text { Gerard } \\
\text { Andrew } \\
\text { Roger }\end{array}$ & Parke & $\begin{array}{l}\text { The Behaviour of Space Trusses Incorporating Novel } \\
\text { Compression Members }\end{array}$ \\
\hline 28 & $\mathrm{PhD}$ & 1989 & Mehdi & $\begin{array}{l}\text { Mohammadi } \\
\text { Khabbazan }\end{array}$ & The Renection Method for the Analysis of Space Frames \\
\hline 29 & $\mathrm{PhD}$ & 1989 & $\begin{array}{l}\text { Peter } \\
\text { Lawrence }\end{array}$ & Disney & The Programming Language Formian \\
\hline 30 & $\mathrm{PhD}$ & 1990 & Wenxiao & Shan & Foldable Space Structures \\
\hline 31 & $\mathrm{PhD}$ & 1990 & $\begin{array}{l}\text { Jackson } \\
\text { Araali }\end{array}$ & Mwakali & $\begin{array}{l}\text { The Collapse Behaviour of Double-layer Space Trusses } \\
\text { Incorporating Eccentrically Loaded Tee-section Members }\end{array}$ \\
\hline 32 & $\mathrm{PhD}$ & 1990 & Barbara Helen & Johnson & $\begin{array}{l}\text { Near-coincident Boubly-symmetric } \\
\text { Imperfaction Sensitivity }\end{array}$ \\
\hline 33 & $\mathrm{PhD}$ & 1992 & Walid S & Shatila & $\begin{array}{l}\text { Computer Analysis, Design and Draughting of Semi-rigid } \\
\text { Bolted Connections }\end{array}$ \\
\hline 34 & $\mathrm{PhD}$ & 1993 & Chiaki & Yamamoto & $\begin{array}{l}\text { New Formian and Epilanguages for Preprocessing of } \\
\text { Space Structures }\end{array}$ \\
\hline 35 & $\mathrm{PhD}$ & 1993 & Deepali & Hadker & Formex Configuration Processing for Space Structures \\
\hline 36 & $\mathrm{PhD}$ & 1993 & $\begin{array}{l}\text { Dimitra } \\
\text { Christos }\end{array}$ & Tzourmakliotou & Computer Aided Design of Braced Domes \\
\hline 37 & $\mathrm{PhD}$ & 1994 & $\begin{array}{l}\text { Eltayeb } \\
\text { Elrayah }\end{array}$ & Khalafalla & Computer Aided Processing of Geodesic Structural Forms \\
\hline 38 & M Phil & 1994 & Hiroyuki & Tomatsuri & Space Structure Forms and Analysis \\
\hline 39 & $\mathrm{PhD}$ & 1997 & Oliver Charles & Champion & Polyhedric Configurations \\
\hline 40 & $\mathrm{PhD}$ & 1997 & Karim & Abedi & Propagation of Local Instability in Braced Domes \\
\hline 41 & $\mathrm{PhD}$ & 1997 & $\begin{array}{l}\text { Mohammad } \\
\text { Reza }\end{array}$ & Chenaghlou & Semi-rigidity of Connections in Space Structures \\
\hline 42 & $\mathrm{PhD}$ & 1999 & Isabell S & Hofmann & $\begin{array}{l}\text { The Concept of Pellevation for Shaping of Structural } \\
\text { Forms }\end{array}$ \\
\hline 43 & $\mathrm{PhD}$ & 1999 & Fevzi & Dansik & Force Density Method and Configuration Processing \\
\hline 44 & $\mathrm{PhD}$ & 2000 & Yoshihiko & Kuroiwa & 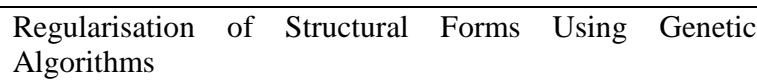 \\
\hline 45 & $\mathrm{PhD}$ & 2000 & $\begin{array}{l}\text { Mohammad } \\
\text { Ali }\end{array}$ & Saeedi & $\begin{array}{l}\text { An Approximate Method for the Prediction of the } \\
\text { Behaviour of Some Space Structures }\end{array}$ \\
\hline 46 & $\mathrm{PhD}$ & 2000 & Olivier L S & Baverel & Nexorade: a Family of Interwoven Space Structures \\
\hline 47 & $\mathrm{PhD}$ & 2001 & Graham & Barnard & $\begin{array}{l}\text { Engineering with Small Roundwood - its Mechanical and } \\
\text { Physical Characteristics }\end{array}$ \\
\hline 48 & $\mathrm{PhD}$ & 2002 & Hossein & Ebrahimi Farsangi & $\begin{array}{l}\text { Topological Optimisation of Double Layer Grids Using } \\
\text { Genetic Algorithm }\end{array}$ \\
\hline 49 & $\mathrm{PhD}$ & 2002 & Arjang & Sadeghi & $\begin{array}{l}\text { Equivalent Earthquake Loads for Some Families of Barrel } \\
\text { Vaults }\end{array}$ \\
\hline 50 & $\mathrm{PhD}$ & 2002 & Mauro & Overend & The Appraisal of Structural Glass Assemblies \\
\hline 51 & $\mathrm{PhD}$ & 2004 & Sana Said & El-Lishani & Cable Domes and Their Stability \\
\hline 52 & $\mathrm{PhD}$ & 2004 & $\begin{array}{l}\text { Mohammad } \\
\text { Hadi }\end{array}$ & Pashaei & Damping Characteristics of Mero-type Double Layer Grids \\
\hline 53 & $\mathrm{PhD}$ & 2004 & $\begin{array}{l}\text { Mohammad } \\
\text { Reza }\end{array}$ & Davoodi & $\begin{array}{l}\text { Effects of Bolt Tightness on the Behaviour of Mero-type } \\
\text { Double Layer Grids }\end{array}$ \\
\hline 54 & $\mathrm{PhD}$ & 2004 & Xenofon & A.Lignos & $\begin{array}{l}\text { A Contribution to the Nonlinear Stability Analysis of } \\
\text { Multiple Parameter System }\end{array}$ \\
\hline 55 & $\mathrm{PhD}$ & 2006 & Mahdi & Moghimi & $\begin{array}{l}\text { Formex Configuration Processing of Compound and } \\
\text { Freeform Structures }\end{array}$ \\
\hline 56 & $\mathrm{PhD}$ & 2006 & $\begin{array}{l}\text { Douglas } \\
\text { William }\end{array}$ & Brown & $\begin{array}{l}\text { Verifying the Correctness of Structural Engineering } \\
\text { Calculations }\end{array}$ \\
\hline
\end{tabular}




\begin{tabular}{|l|l|l|l|l|l|}
\hline 57 & $\mathrm{PhD}$ & 2007 & Karl-Heinz & Friedrich Stech & Efficiency of Bridge Structures \\
\hline 58 & $\mathrm{PhD}$ & 2008 & Pierre & Farrugia & Kinematic Analysis of Foldable Structures \\
\hline 59 & $\mathrm{PhD}$ & 2009 & Masoud & Bolourian & Theory of Plenices \\
\hline 60 & $\mathrm{PhD}$ & 2012 & Akbar & Rahimi Noshnagh & Suspen-domes: Study of the Behaviour and the Design \\
\hline
\end{tabular}

Figure 2: List of the completed M Phil/PhD dissertations in the Centre.

A new algebra, namely, formex algebra, and its accompanying programming language Formian were developed for configuration processing of spatial structures. The early work in formex configuration processing in the seventies was greatly helped by substantial donations from a group of Iranian Engineers, Figure 3. These are A. Sarshar, A. Jahanshahi, C. G. Abkarian, G. A. Mirzareza, M. S. Yazdani and J. Hassanein. Also, during the nineties, the Taiyo Kogyo Corporation of Japan, NASA (Award No NAGW-4132) and the Tomoe Corporation of Japan were instrumental in supporting research in formex configuration processing.

Figure 3: Some of the donators are seen in the picture. From left: A. Sarshar, M. S. Yazdani (H Nooshin and M Ghalibafian), C. G. Abkarian, G. A. Mirzareza and A. Jahanshahi [5].

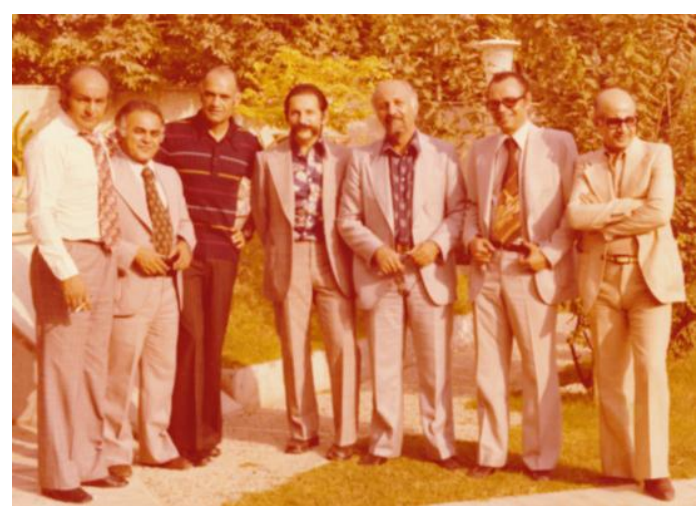

\section{Publications}

Over the years the Centre has been responsible for the publication of a number of books, papers and conference proceedings. In particular, the Centre was involved in the publication of the International Journal of Space Structures since 1985.

\subsection{Books}

The following nine books, which are valuable references in the field of spatial structures, have been published by the Centre:

Makowski Z.S., Räumliche Tragwerke aus Stahl. (1st ed. in German), Verlag Stahleisen m.b.H., 1963.

Makowski Z.S., Constructions Spatiales en acier. (1st ed. in French), Verlag Stahleisen m.b.H., 1963.

Makowski Z.S., Steel Space Structures. (1st ed. in English), Verlag Stahleisen m.b.H., 1964.

Bunni U.K., Disney P. and Makowski Z.S., Multi-layer Space Frames., Constrado, 1980.

Makowski Z.S., Analysis, Design and Construction of Double Layer Grids., Applied Science Publishers LTD, 1981.

Nooshin H., Formex Configuration Processing in Structural Engineering., Elsevier Applied Science Publishers LTD, 1984.

Makowski Z.S., Analysis, Design and Construction of Braced Domes., Granada Publishing, 1984.

Makowski Z.S., Analysis, Design and Construction of Braced Barrel Vaults., Elsevier Applied Science Publishers LTD, 1985.

Nooshin H., Studies in Space Structures., Multi-Science Publishing Company Limited, 1987.

\subsection{International Journal of Space Structures}

The first issue of the International Journal of Space Structures was published in 1985. According to the Editorial Note by the founders and initial editors of the Journal, Z S Makowski and H Nooshin, 'the need for a journal dealing specifically with space structures was felt long before the recent International Conference on Space 
Structures, which was held at the University of Surrey in September 1984. The success of the conference reinforced the belief that the time was now ripe for the launching of a journal on space structures.' Twenty one years later, in 2006, Rene Motro and John Chilton were appointed as the new editors of the Journal. Later on in 2008, Motro carried on with the editorship alone. In 2012, he decided to focus on his position as the president of the International Association for Shell and Spatial Structures, so he passed the responsibility of the editorship to Olivier Baverel and Bernard Maurin. The Journal has published 28 special issues on specific subjects, Figure 4. The figure gives information about these special issues including the subject and the name of the Guest Editor(s).

\begin{tabular}{|c|c|c|c|c|}
\hline Vol & No & Year & Subject of the Special Issue & Guest Editor(s) \\
\hline 5 & $3 \& 4$ & 1990 & Geodesic Forms & Tibor Tarnai \\
\hline 7 & 4 & 1992 & Stability of Space Structures & Victor Gioncu \\
\hline 8 & $1 \& 2$ & 1993 & Deployable Space Structures & Sergio Pellegrino \\
\hline 10 & 3 & 1995 & Prefabricated Spatial Frame Systems & Ariel Hanaor \\
\hline 11 & $1 \& 2$ & 1996 & Morphology and Architecture & Haresh Lalvani \\
\hline 12 & $3 \& 4$ & 1997 & Dynamics of Space Structures & Yasuhiko Hangai \\
\hline 14 & 2 & 1999 & Form Finding of Tension Structures & Rene Motro \\
\hline 14 & 3 & 1999 & Aircraft Hangers & G. S. Ramaswamy \\
\hline 15 & $3 \& 4$ & 2000 & Topics in Design of Lattice Structures & Ariel Hanaor \\
\hline 16 & 3 & 2001 & Space Structures in China & Tien T Lan \& S. Z. Shen \\
\hline 17 & $2 \& 3$ & 2002 & Teaching of Space Structures & John Chilton \\
\hline 21 & 1 & 2006 & The Pioneers of Space Structures & ----- \\
\hline 22 & 1 & 2007 & Footbridges & Enzo Siviero \\
\hline 22 & 3 & 2007 & Adaptable Structures & Arno Pronk \\
\hline 23 & 4 & 2008 & Tensioned Membrane Construction & Marijke Mollaert \& John Chilton \\
\hline 24 & 2 & 2009 & Structural Engineers World Congress & R. Sundaram \\
\hline 24 & 4 & 2009 & Structural Membranes: Analysis and Design & Eugenio Oñate \\
\hline 25 & 2 & 2010 & Computation of Spatial Structures & John F. Abel \\
\hline 26 & 3 & 2011 & Celebrating 25 Years Devoted to Space Structures & ----- \\
\hline 26 & 4 & 2011 & Reciprocal Systems & Olivier Bavarel \\
\hline 27 & $2 \& 3$ & 2012 & Tensegrity & Gian Carlo Giuliani \\
\hline 28 & $3 \& 4$ & 2013 & Active Bending & Christoph Gengnagel \\
\hline
\end{tabular}

Figure 4: List of the special issues of the International Journal of Space Structures including the subjects and the guest editor(s).

\section{Teaching}

The Centre has been active in offering courses on spatial structures at various levels during the past 50 years. Specifically, a course entitled 'Space Structures' for postgraduate students of the University of Surrey has been designed and delivered since 1964. The Centre has organized a celebration on the occasion of the $50^{\text {th }}$ year of teaching the course by Prof H Nooshin on 25 March 2013, Figure 5. Also, various workshops and short courses at different levels have been organised by the Centre in the UK and other countries including Australia, China, India, Iran, Japan and Romania. Figure 7, for instance, shows a group of primary school students, during a one day workshop on 'basics of form generation in Formian' in the University of Surrey, UK. Another example of the many teaching activities is a two week course on spatial structures. The course was organised for its $19^{\text {th }}$ time in April 2014 at the University of Kerman, Iran. Figure 8 shows a group of attendees of the course in 2001. 


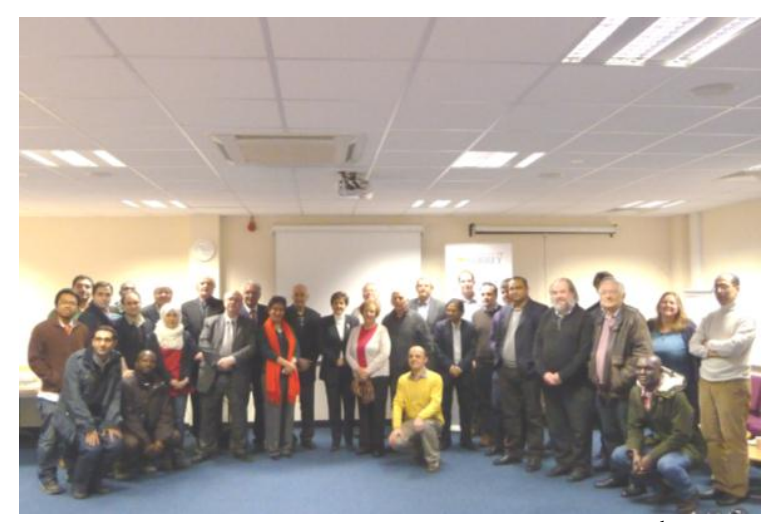

Figure 5: A celebration on the occasion of $50^{\text {th }}$ year of teaching Spatial Structures, 25 March 2013 [5].

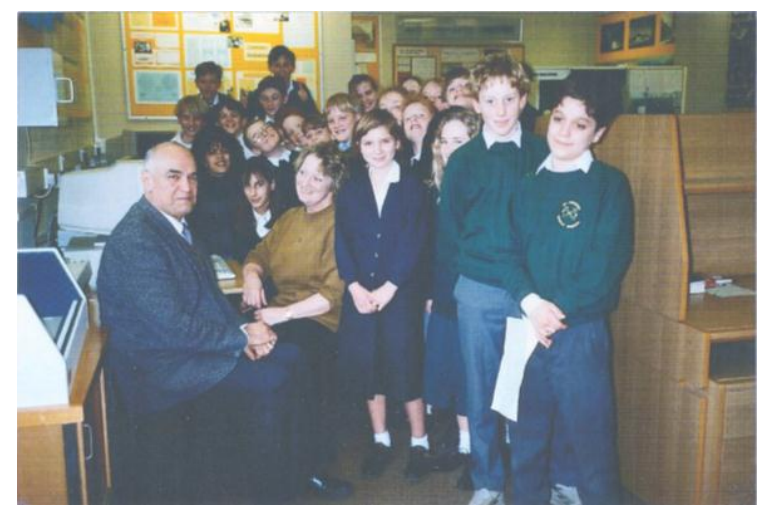

Figure 7: A group of primary school students at the Centre, during a one day workshop on 'basics of form generation in Formian’ [5].

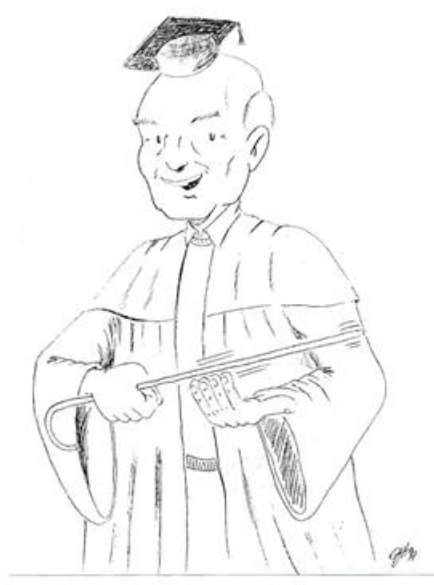

Figure 6: A caricature of Prof $\mathrm{H}$ Nooshin by one of his placement year students during a regular visit

[5].

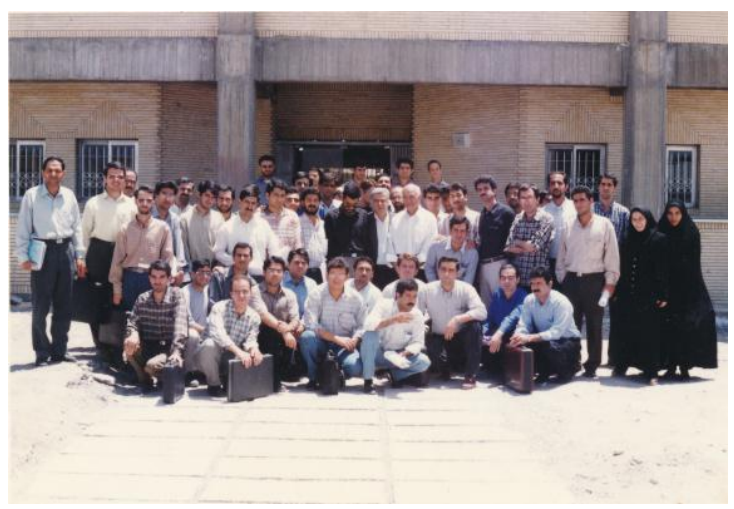

Figure 8: Some attendees of the two week course on spatial structures in the University of Kerman, Iran, 2001 [5].

\section{Conferences}

A series of International Conferences on Space Structures has been organised by the Centre, the first of which was in 1966. The last conference in this series was combined with an IABSE-IASS event in London, 2011. The proceeding of the first conference, held in 1966, edited by R M Davies, the second one in 1975, edited by W J Supple, the third one in 1984, edited by H Nooshin, the fourth one in 1993, edited by G A R Parke together with C M Howard and the fifth one in 2002, edited by G A R Parke and P Disney. These proceedings are recognised as major contributions to the development of space structures technology and architecture. The first conference brought over 700 participants from 44 countries, the second, some 400 engineers from 51 countries, the third one over 500 engineers and architects from 63 countries, the fourth, some of 400 participants and the fifth one over 400 engineers and architects. Figures 9 and 10 show two memorial gifts to the Centre given by the Mero Company and the British Aluminium Company on the occasions of the Second and the Third International Conferences, respectively.

Also, the Centre was involved in organising a number of seminars in association with other organisations. Figure 11 shows one of such seminars on formex algebra and Formian, Osaka, Japan, 1990. 


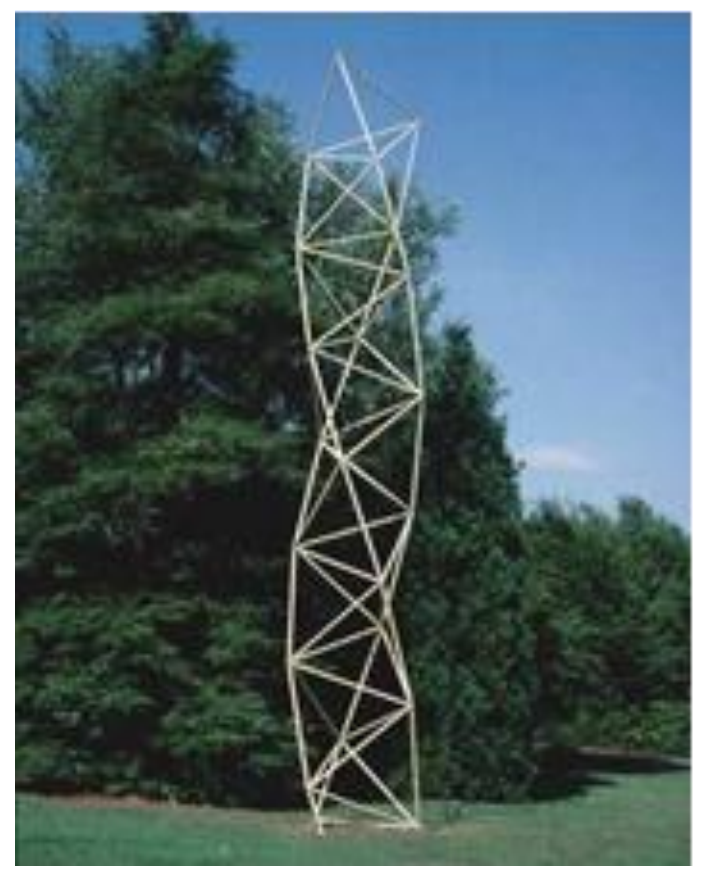

Figure 9: A 10m height Steel memorial gift by the German Mero Company on the occasion of the Second International Conference on Space Structures, University of Surrey, September 1975 [5].

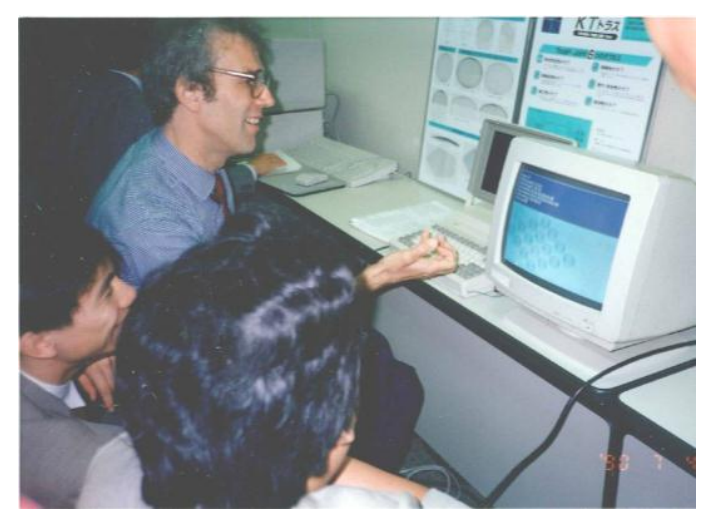

Figure 11: A seminar on formex algebra and Formian, Osaka, Japan, 1990. The left picture shows Dr Peter Disney demonstrating the initial versión of Formian in the conference [5].

\subsection{Pioneers' Award}

It has been a tradition of the Space Structures Research Centre to recognise and honour those who have made significant contributions in the field of spatial structures. This has been done through a special award called the "Pioneers' Award", given during the International Conferences on Space Structures held at the University of Surrey. List of the recipients of the Pioneers' Award is given in Figure 12. Also, two examples of the Award are presented in Figure 13. 


\begin{tabular}{|l|l|}
\hline The Third Conference in 1984 & The Fifth Conference in 2002 \\
\hline Francisco Castano (Mexico) & Michael Burt (Israel) \\
\hline Stephane du Chateau (France) & Mick Eekhout (Netherlands) \\
\hline H G Fentiman and A E Fentiman (Canada) & Felix Escrig (Spain) \\
\hline Fujio Matsushita (Japan) & J Francois Gabriel (USA) \\
\hline Max Mengeringhausen (Germany) & Victor Gioncu (Romania) \\
\hline Donald L Richter (USA) & Kajal K Gupta (USA) \\
\hline Yoshikatsu Tsuboi (Japan) & Ariel Hanaor (Israel) \\
\hline & Kazuo Ishii (Japan) \\
\hline The Fourth Conference in 1993 & Shiro Kato (Japan) \\
\hline Jan Bobrowski (UK) & Haresh Lalvani (USA) \\
\hline David G Emmerich (France) & M Majowiecki (Italy) \\
\hline Yasuhiko Hangai (Japan) & Stefan J Medwadowski (USA) \\
\hline Yoshito Isono (Japan) & Rene Motro (France) \\
\hline Mamoru Kawaguchi (Japan) & Sergio Pellegrino (UK) \\
\hline Tien T Lan (China) & Ekkehard Ramm (Germany) \\
\hline Lewis C Schmidt (Australia) & Masao Saitoh (Japan) \\
\hline Mircea V Soare (Romania) & Jorg Schlaich (Germany) \\
\hline Ronald G Taylor (UK) & Tibor Tarnai (Hungary) \\
\hline
\end{tabular}

Figure 12: List of the Pioneers' Award recipients given during the International Conferences on Space Structures.
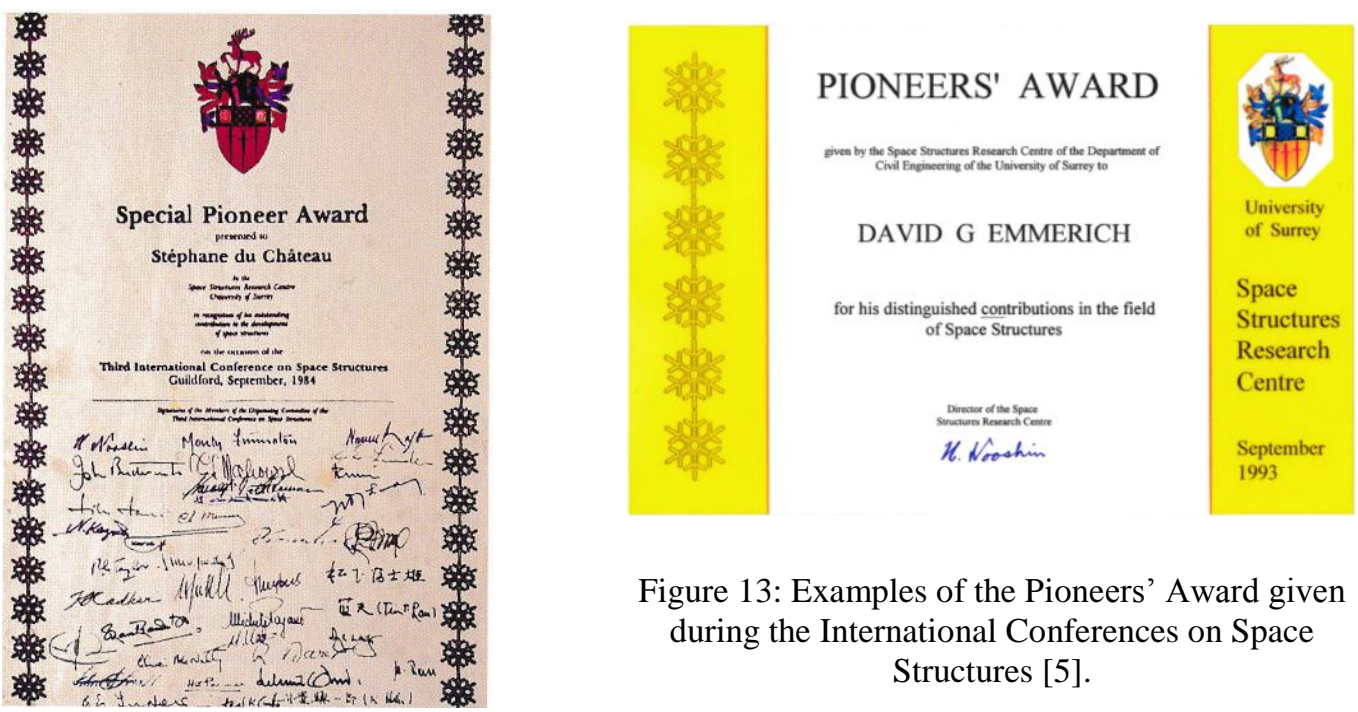

Figure 13: Examples of the Pioneers' Award given during the International Conferences on Space Structures [5].

\section{Contributions to the industry}

A number of firms, specialised in spatial structures, have been in close relation with the Centre. The technical staff of the firms, as well as the managers, have been sent to the Centre to expand their knowledge. These include the famous Japanese firms of Taiyo Kogyo Group and Tomoe Corporation. Figure 14 shows an annual gathering of the "Surrey Club" at the Taiyo Kogyo Company, Tokyo, March 1993. Also, consulting work has been carried out in the Centre including the design of the Jumbo Jet Hangars at London Heathrow Airport, Figures 16, and the prestressed cable roof of the Farahabad (Takhti) Sports Stadium in Tehran, Figure 17. 


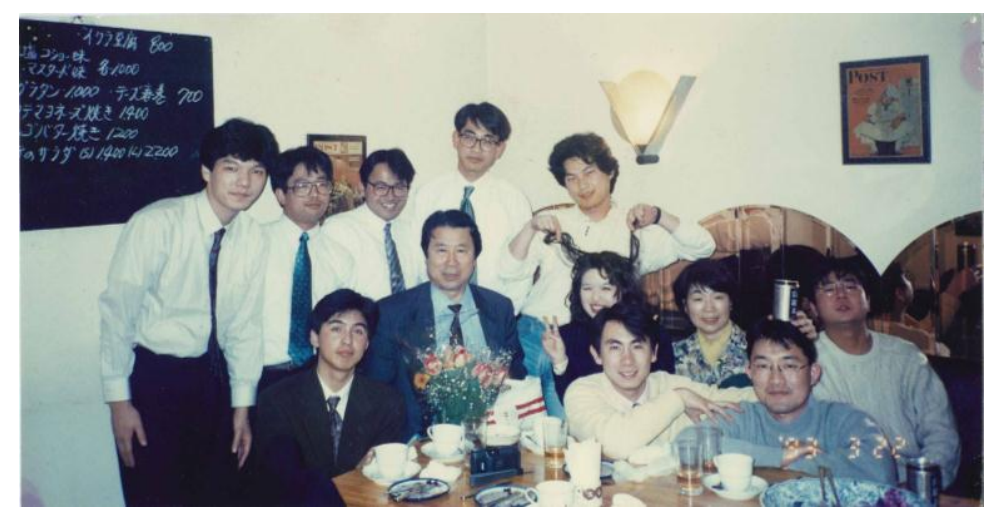

Figure 15: Annual gathering of the "Surrey Club" at the Taiyo Kogyo Company, Tokyo, March 1993 [5].

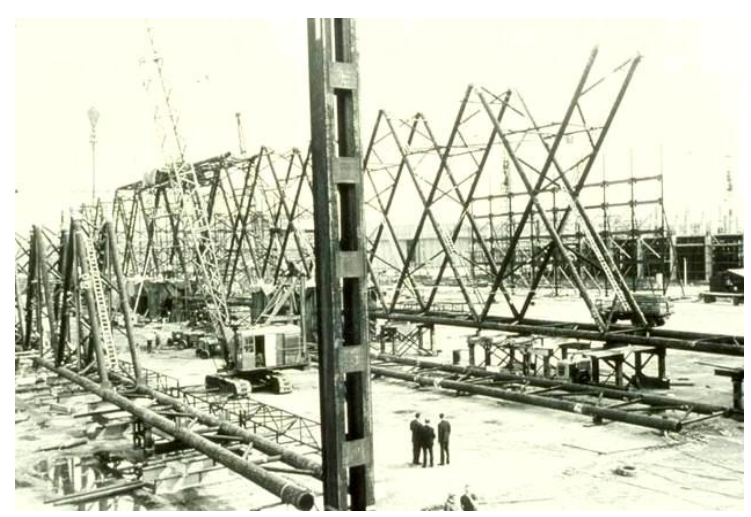

Figure 16: Spine girder and fascia girder of the Jumbo Jet Maintenance Hangar 01 at Heathrow Airport during the construction, London, UK, 1969 [5].

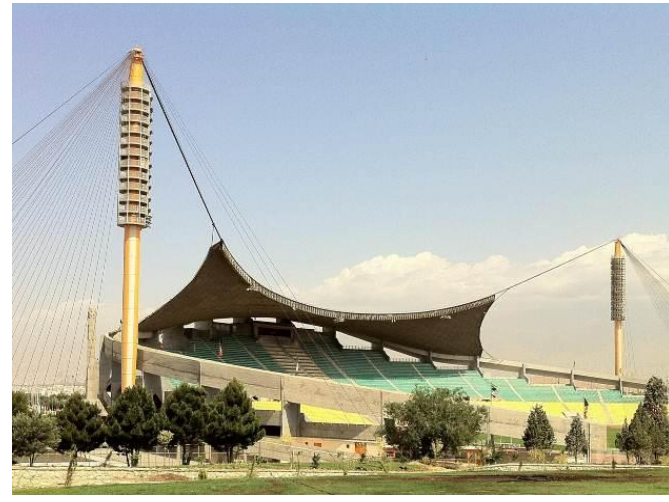

Figure 17: Takhti (Farahabad) Sports Stadium in Tehran, Iran, opened in 1974, photo by Omidali Samavati [4]

In 2014, the Research Centre is still continuing with its strong commitment into understanding further structural morphology, as well as the behaviour of spatial structures with over $10 \mathrm{PhD}$ students engaged in this work.

\section{References}

[1] Douglas R., SURREY The Rise of a Modern University, University of Surrey, 1991.

[2] Mitchell J., The University of Surrey: A History of Shaping the Future, University of Surrey. University of Surrey, 2011.

[3] Pick C., Understanding the Real World: A visual history of the University of Surrey, The University of Surrey Press, 2002.

[4] Samavati O., Personal Archive.

[5] Space Structures Research Centre Archives, University of Surrey.

[6] Surrey Research Insight, http://epubs.surrey.ac.uk/. 